\title{
Kirkebygninger i religionsmodellens grænseflade. Mellem fælles kulturarv og folkekirkeligt magtmonopol
}

\author{
HANS RAUN IVERSEN
}

ENGLISH ABSTRACT: The organization and work of The Danish National Church form the core of the Danish model of religion. One might, therefore, think that this would also include the church buildings used by the church. I argue that the church buildings used by The National Church and especially the pre-Reformation buildings are placed in the borderland of the Danish model of religion, since they belong to the common cultural heritage although they are administered by the church. I analyze the historically conditioned ownership followed by an outline of the interpretations of the buildings endorsed by respectively the official church and its members. The special situation pertinent to the church buildings of Copenhagen is described before the final analysis of the principles underlying the decision by the Minister of Cultural Affairs on the bishop's suggestion to close down 14 churches in Copenhagen in 2013. I conclude that church buildings in Denmark hold a status similar to holy cows in India.

DANSK RESUME: Folkekirkens organisation og virksomhed udgør den danske religionsmodels kerneområde. Herudfra slutter man let, at det også må gælde de kirkebygninger, som folkekirken gør brug af. Det er denne artikels tese, at folkekirkens kirkebygninger, og særligt den dominerende del af dem, som er bygget for reformationen, hører hjemme $i$ den danske religionsmodels grænseflade. Dette fordi de tilhører den fxlles kulturarv, selv om de er undergivet folkekirkelig administration. Artiklen beskriver først bygningernes historisk betingede ejendomsretlige status, dernæst den folkelige og kirkelige tolkning af bygningerne, og endelig redegøres der for de særlige forhold omkring kirkerne $i$ København. Til sidst analyseres de principielle retningslinjer om kirkebygninger, der kommer til orde gennem Kulturministerens afgørelse af 14 kirkelukningssager i Københavns Stift i 2013. Konklusionen lyder, at kirkebygningernes status $i$ Danmark er sammenlignelig med de hellige køers status i Indien.

KEYWORDS: Church buildings; common cultural heritage; ownership; state church 


\section{Kirkebygningernes ejendomsretlige status}

Den 1. januar 2014 var 4.413.825 af de i alt 5.627.235 indbyggere i Danmark medlemmer af den danske folkekirke. Det svarer til 78,4 procent af alle indbyggere. Der er 2.354 folkekirkelige kirkebygninger placeret i 2.123 sogne. Sognene dækker hele landet og bestyres af 1.935 menighedsråd, organiseret i 104 provstier med økonomistyrende provstiudvalg valgt af menighedsrådsmedlemmerne i provstiet. Provstierne, der geografisk ligner kommunerne, indgår i ti stifter, der administrativt ledes af stiftsøvrigheden, der består af en menighedsrådsvalgt biskop og en statsansat regionsdirektør. Der findes endvidere rådgivende stiftsråd, valgt af stiftets menighedsrådsmedlemmer (www.km.dk).

Ca. 1700 af folkekirkens kirkebygninger er bygget i katolsk tid før reformationen i 1536. ${ }^{1}$ Det gør, at kirkernes ejerforhold er vanskeligt at udrede. Formelt er kirkerne selvejende, men reelt er de en slags alle-mands-eje på linje med de danske kystarealer, som er tilgængelige for alle. Den historiske baggrund for kirkebygningernes status er lang og kompliceret. I kort udgave ser den således ud: ${ }^{2}$

Den reformatoriske kirke overtog den katolske kirkes økonomiske grundlag med tredelt tiende, hvoraf en tredjedel gik til bisperne, en tredjedel til præsterne og en tredjedel til kirkerne. Bispetiende blev til kongetiende, idet kongen til gengæld betalte bispernes lønninger. I 1903 blev alle former for tiende afløst, dvs. at tienderetten blev overtaget af staten mod en kompensationskapital til kirkerne. For bisperne er resultatet den dag i dag, at de aflønnes af staten. Kapitalen fra præstetiende indgik i præstelønningsfonden, i dag Folkekirkens Fællesfond, der aflønner præsterne og primært får sine midler fra landskirkeskatten, men også fra finansloven

Kirkernes tienderet bidrog til, at kirken før reformationen var en slags stat i staten, ligesom kommuner og amter/regioner senere blev det. En instans med egne faste indtægter har en vis selvstændighed, selv om det, som tilfældet også er med kommuner og regioner i dag, foregår under statens tilsyn. Men at være en instans med egen økonomi kan være farligt, hvis staten fattes penge, når staten vel at mærke er blevet suveræn, som det skete i Danmark med reformationen i 1536 og blev understreget med enevælden af 1660 .

I tre omgange berigede den slunkne statskasse sig med kirkernes midler: først ved ekspropriation af bispetiende og en række godser og klostre i reformationen, svarende til en tredjedel af landets jord, og siden ved salg af de lokale kirker med deres rettigheder (tiende og præstekaldelse) og pligter (drift og vedligeholdelse) til velstående, private entreprenører eller patroner i 1600- og 1700-tallet. Præstegårdene

1 I Betænkning 1511 kategoriseres folkekirkens kirkebygninger efter opførelsestidspunkt: Før 1250: ca. 1650, 1250-1600: ca. 100, 1600-1850: 48, 1850-1910: 237, 1911-1960: 178 og 1961-2008: 139 (Betænkning 1511, 2009, 46). Pointen i sammenhæng med denne betænkning om statens "tilskud" til kirken, er, at de kirkeskattemidler, der bruges til simpel bevarelse af kulturarven i de gamle kirkebygninger (knapt 1 milliard kr. om året) er på højde med statens "tilskud" til kirken (Betænkning 1511, 2009, 13).

2 Den bedste samlede, historiske redegørelse for kirkens økonomi og ejerskabsforhold findes i Stenbæk (2003), som denne fremstilling støtter sig til. 
med deres jord blev i 1661 bortgivet til fattigvæsenet for at sætte det i stand til at tilbagebetale en betydelig gæld til en række private institutioner. Derfor måtte præsterne fremover købe sig til retten til at bebo og bruge præstegården, først fra fattigvæsenet og siden fra forgængeren i embedet. Dette førte til, at den nye præst ofte måtte gifte sig med den gamle præsts enke for at få tag over hovedet. Efter 1849 tilbagekøbte sognekirkerne præstegårdene fra præsterne, men i 1919 blev op mod 10.000 hektar præstegårdsjord eksproprieret, så der kunne udstykkes 1140 husmandssteder på jorden (Stenbæk 2003, 142). I dag hører det til undtagelserne, hvis kirkerne ejer, endsige dyrker jord eller driver anden form for indtægtsgivende virksomhed.

For kirkepatronernes forhold til kirkebygninger og kirkegårde såvel som for præsternes forhold til præstegårdene gjaldt det, at forholdet var usefructarisk: Man havde brugsretten og kunne nyde et eventuelt overskud fra driften, men var ikke suveræn ejer af nogen af delene. Dette fordi både kirken, kirkegården og præstegården til enhver tid skulle opfylde bestemte formål, nemlig kirkens lokale drift. I den lovgivende rigsforsamling søgte man i foråret 1849 at beskytte kirkernes ejendom og drift ved at få indført en paragraf $66 \mathrm{~d}$, hvor det hed: “De til Kirken, Skolen eller milde Stiftelser henlagte eller skiænkede Eiendomme og Midler kunne ikke anvendes til noget fremmed Øiemed" (citeret efter Stenbæk 203, 125). Selv om denne paragraf var indstillet med ti stemmer mod fem fra den lovforberedende komite, der kunne henvise til de nævnte fortilfælde for statsligt overgreb på kirkelig ejendom, faldt den med et brag. Dette skete primært på grund af modstanden mod at cementere kirkers og andre mere eller mindre herreløse institutioners muligheder for at fungere som små stater i staten. Debatten afspejlede imidlertid den situation, som enevælden og statskirken havde tilsløret: Kirken med dens forpligtelser og ejendom handler ikke blot om forholdet mellem stat og kirke. Det handler om et forhold med tre parter: folk, stat og kirke. Siden reformationen har staten suverænt styret - og ofte udnyttet - kirken. Det rejser spørgsmål, som også er aktuelle i dag: Hvad med folket? Hvordan kan man forhindre, at kirken kommer til at stå som en selvstændig instans både over for folk og stat? For hvis kirken bliver for selvstændig, er man så ikke vendt tilbage til en katolsk kirkeforståelse, hvor kirken reelt kommer i hænderne på et gejstligt hierarki? Men hvad sker der omvendt, hvis staten overtager kirkerne? Hvordan stiller det folket - og folkekirken? Disse ubesvarede spørgsmål om kirkebygningernes ejerskab var i høj grad medvirkende til udsættelse af den i grundloven forudsatte ordning af folkekirkens styrelsesforhold på ubestemt tid (Andersen 1992; Iversen 1993).

Med grundloven fratrådte kongen som enevældigt statssubjekt, men staten regerede via regering og folketing videre som kirkebestyrelse. Men grundlovens principper måtte også implementeres i folkekirken. Man kunne ikke længere have herremænd og adelsfolk af særlig rang og stand til at herske over de lokale kirkebygninger og præsteansættelser. I en omfattende kirkereguleringslov af 1861 sørgede man 
for at få afskaffet betegnelser som kirkeejer og patron, idet man i stedet talte om kirketiendeejeren (Stenbæk 2003, 136). Men man kunne ikke i længden undvære en kirkelig organisation, som kunne afløse de ofte lemfældige kirketiendeejere som bestyrere af kirkebygningerne. I første omgang ordnede staten paragrafferne, først ved at Kultusministeriet overtog præsteembedernes besættelse, siden ved at man fra 1903 regulerede kirkernes indtægter gennem afskaffelse af diverse kirkeafgifter og tiendebetaling. Efterfølgende blev kirkeskatten indført, efterhånden som renterne fra kapitalerne fra salg af tienderetten blev ædt op af inflationen. Men i anden omgang kom man - med de af I.C. Christensen promoverede kirkelove fra 1903, $1912 \mathrm{samt}$ 1922 - ikke uden om at opbygge et lokalt kirkeligt forvaltningsvæsen med menighedsråd og provstiudvalg. Dette fik dog først i 2004 fuldmagt til at fastsætte sognekirkernes indtægter (lokal kirkeskat) og udgifter uden adgang til indblanding fra hverken kommunalbestyrelsen eller kirkeministeriet (Iversen 2003; Malmgart 2003). Først i 2007 blev det slået fast i Lov om Menighedsråds §1, at menighedsrådet kontrollerer ikke blot bygninger og penge, men også de kirkelige anliggender i sognet. Hvor man tidligere kunne tolke menighedsrådene som kirkebestyrere på statens/offentligheden vegne, er det i dag mere klart, at menighedsrådene er kristne bestyrelser for en kristen kirkes lokale virksomhed.

Den gordiske knude omkring kirkebygningernes bestyrelse fandt en langtidsvirksom løsning med indførelsen af menighedsrådene fra 1903. De fleste kirketiendeejere så en fordel $\mathrm{i}$ at afhænde deres kirkelige rettigheder og forpligtelser, og kirkerne overgik hurtigt efter 1903 til selveje under bestyrelse af de lokale menighedsråd. Der var nok at tage fat på, begyndende med tiltrængt opvarmning og hygge i kirkerne, som blandt andre I.C. Christensen savnede. I dag fungerer menighedsrådene som lokale virksomhedsbestyrelser med hver deres sognekirke(r)s vedligeholdelse og drift som deres suveræne domæne. De er dog underlagt et hierarki af kirkelige og statslige tilsynsmyndigheder, som skal godkende og helst også designe selv de mindste ændringer i bygningerne (jf. Rapport 2013).

Fra 1908 skulle menighedsrådene udpege to medlemmer til at have tilsyn med de selvejende kirkebygninger. I tiden 1910-12, hvor der ikke var legale menighedsråd pga. prøvetidens udløb og uenighed om lovens endelige udformning i folketinget, var det pålagt sognerådene på landet at udpege de to medlemmer til kirketilsynet. I henhold til loven om kirkers bestyrelse fra 1915 skulle kirkerne bestyres af menighedsrådene suppleret med et medlem udpeget af sognerådet (Stenbæk 2003, 139). Det eksterne medlem af kirkebestyrelsen blev set som et udemokratisk levn fra de gamle kirkeinspektorater i købstæderne, så sognerådsrepræsentanten røg ud af kirkebestyrelserne ved kirkelovene fra 1922. Dette selv om de radikale stemte for bibeholdelse og socialdemokraterne for udvidelse af den kommunale repræsentation $\mathrm{i}$ kirkebestyrelserne (Malmgart 2003, 42; Stenbæk 2003, 139f.). Tilbage stod kun en formel paragraf om, at kommunalbestyrelserne kunne protestere, hvis kirkeskatten steg for meget. Paragraffen var uden praktisk betydning og blev afskaffet med virk- 
ning fra 1. januar 2004. Kirkeminister Tove Fergo søgte at indsætte sig selv som økonomisk kontrolinstans i kommunalbestyrelsernes sted, men måtte opgive pga. modstand mod denne statskirkelighed (Iversen 2003).

\section{Kirkebygningerne i den danske religionsmodel}

Stenbæk fremhæver, at adskillelsen mellem kirkelige og kommunale myndigheder har været karakteristisk for folkekirken siden 1922. I.C. Christensens argument for denne adskillelse var dels henvisningen til de sønderjyske ordninger, der skulle samkøres med resten af folkekirken efter genforeningen i 1920, dels at menighedsrådet sagtens selv kunne klare kirkebestyrelsen. Det var jo folk valgt af den samme befolkning, der sad i henholdsvis menighedsråd og sogneråd eller kommunalbestyrelser. Det var alt sammen rigtigt i 1922, hvor 98 procent og på landet ofte praktisk talt 100 procent af befolkningen var medlemmer af folkekirken.

I første omgang kan man pege på en række positive følgevirkninger af menighedsrådenes arbejde som kirkebestyrere i Danmark. Opvarmningen og vedligeholdelsen er i absolut topklasse i så godt som alle kirker. Det er menighedsrådenes stolthed, at det skal være sådan, og de kan som regel let skaffe de økonomiske midler via deres repræsentant i det kirkeskatudskrivende provstiudvalg. Det har utvivlsomt positive kirkelige følger, at man ikke, som i begyndelsen af 1800-tallet, behøver at gribe til hjemmedåb af frygt for, at dåbsbørnene skal pådrage sig lungebetændelse. Kirkernes nye kirkelige praksisformer som åbne kirker, vejkirker, natkirker, babysalmesang etc. har, sammenholdt med en stigende interesse for kirketurisme og pilgrimsvandringer, især i de seneste årtier åbnet kirkebygningerne op, så det i dag kun er et mindretal af befolkningen, der aldrig kommer i en kirke. Hvor kirkerne i årene efter anden verdenskrig blev fjernere og fjernere for den ikke-kirkeligt traditionsbundne del af befolkningen, betyder det at gå i kirke i dag for mange mennesker at gå ind i en kirke uden nødvendigvis at deltage $\mathrm{i}$ et autoriseret ritual. De fleste kommer dog i kirkerne til de kirkelige handlinger (dåb, konfirmation, bryllup og begravelse), hvor den enkelte handling i dag har langt større deltagelse end tidligere.

Ifølge en undersøgelse blandt 897 repræsentativt udvalgte danskere, foretaget af Epinion for DR Nyheder, har 61 procent af danskerne (over 18 år) været i kirke én eller flere gange i 2013. På spørgsmålet “Tænk på sidste gang, du besøgte en kirke. Hvad var anledningen til dit besøg i en kirke?" stillet af YouGov april 2013 med svar fra 1005 respondenter, fordelte svarene sig således at 81 procent havde været til begravelse, dåb, bryllup, højtid eller lignende, 7 procent til almindelig gudstjeneste og 11 procent $\mathrm{i}$ forbindelse med turisme, koncerter, foredrag eller andet (Højsgaard \& Iversen 2013). ${ }^{3}$

3 I procent: Begravelse: 31, Dåb: 18, Højtid: 12, Bryllup: 10, Konfirmation: 10, Almindelig gudstjeneste: 7 Turisme: 5, Koncert 3, Foredrag: 1, og Andet: 2 (Højsgaard \& Iversen 2013). 
Det er et politisk spørgsmål, om de kirkeligt valgte og tænkende menighedsråd plus/minus biskoppen skal have eneret til at bestemme over kirkebygningerne og deres brug i et stadigt mere religiøst mangfoldigt samfund. Først den 3. april 2013 blev Lov om bestyrelse og brug af folkekirkens kirker ændret, så det nu er tilladt at låne eller leje kirkebygningerne ud til ikke-lutherske menigheders gudstjenester og kirkelige handlinger. Dette gælder især til de mange nye migrantkirker, som, allerede før det blev lovliggjort, var rykket ind i folkekirkens bygninger omkring 50 steder. Men menighedsrådene kan fortsat sige nej til at låne eller leje kirken ud til medkristne, herunder også til evangelisk-lutherske fri- og valgmenigheder. Menighedsrådene får erfaringsmæssigt oftest biskoppens opbakning, hvis deres afslag ankes til biskoppen. Freden i kirken sikres ved, at menighedsrådene ikke pånødes uønskede gæster i 'deres' kirke. Hertil kommer endelig, at der først ved en lovændring af 25. marts 2014 blev åbnet legal adgang til, at menighedsrådene kan "stille kirken til rådighed for ikke-kirkelige formål" - dog kun med biskoppens udtrykkelige tilladelse, og kun for aktiviteter, der "ikke strider mod kirkerummets karakter" (Lov om bestyrelse og brug af folkekirkens kirker m.m., §5, stk. 2). Der er tale om vage formuleringer, åbne for fortolkning af biskop og menighedsråd, der fortsat har magten over kirkebygningernes brug.

Den danske statsmodel er generelt karakteristisk ved at have en tynd, men stærk statslige lovgivning, der overlader meget til lokale forhandlinger og afgørelser, sådan som det tydeligst kendes fra arbejdsmarkedets regulering (Iversen 2012, 25f). Samme princip gælder for kirkebygningerne, men her med den komplikation, at der ikke er plads til meget lokal forhandling, fordi de stadigt mere kirkeligt tænkende menighedsråd kan bestemme uden forhandling over kirkebygningernes brug. Hvor bygningerne af gode historiske grunde må placeres i religionsmodellens grænseområde, er de således forvaltningsmæssigt placeret sammen med religionsmodellens kerneaktører i folkekirkens menighedsråd.

\section{Folkelige og kirkelige tolkninger af kirkebygningerne}

Da jeg den 20. september 2011 ankom til Tongji Universitet i Shanghai for at holde gæsteforelæsning, blev jeg mødt af en tre meter høj plakat med et billede af en dansk landsbykirke på annonceringen af forelæsningen. Plakatens størrelse var imponerende, men det mest slående var billedet af middelalderkirken, som i Kina blev brugt som logo for det fjerne Danmark. Sandt er det, at kirkebygningerne overalt i landskabet og byernes skyline fylder langt mere end Den lille havfrue og Tivoligarden, og hvad vi ellers prøver at markere os med. Mindre klart er det, hvordan kirkebygningerne skal tolkes: Er de kristne helligdomme, måske en slags missionsstationer eller er de kulturhistoriske bygninger i det fælles danske landskab? 
Nytårsdag 1944, fire dage før han blev likvideret af besættelsesmagten, holdt Kaj Munk sin sidste prædiken eller snarere antiprædiken. Det skete fra korbuen i Vedersø Kirke, hvor han indledte sit opgør med sognets værnemagere med følgende bøn:

Kære Vor Gud og Far i det høje, vi takker dig for, at du har rejst dit Hus her på Jorden, for at sandheden skulle eje sin faste Borg iblandt os. Tak, at du ogsaa på denne Nytaarsdag 1944 har kaldt os herhen. Der er nok, der lyver i Verden. Her lyder dit Ord, der ikke spørger efter Bifald og ikke regner med Vrede, men er lige sikkert til Trøst og til

Tugt. Om vi saa maatte tage imod det. Amen (Munk 1948, 356).

Allerede i 1926, efter kun to år i embedet, havde Kaj Munk holdt en prædiken med form som en dramatiseret fabel om kirkens møde gennem århundrederne med først katolske messedrenge og siden mølle-, skole- og forsamlingshus- og missionshusbyggeri. Men det er dog, siger Munk, i kirken, Jesus lyser sin velsignelse over hele sognet: "Herren løfte sit Aasyn paa dig og give dig Fred" (Munk 1948, 15). Kaj Munk artikulerede og dramatiserede mere end folk flest, men sogneboerne føler også for den kirkebygning, der både er det faste vartegn for deres hjemsted og det ældste vidnesbyrd om den menneskelige historie på deres sted.

Man behøver ikke være så kristeligt forankret som Kaj Munk for at værne om den lokale kirke. Det fik aktivister fra den ellers fredelige Thylejr at føle, da de gik over stregen ved at besætte Hjardemål Kirke den 31. august 1970 som en protest mod det etablerede Danmark. Sognebeboerne mødte op med forke og leer for at rydde deres kirke for aktivister, så aktivisterne til sidst måtte lade det etablerede Danmarks politi beskytte sig mod korporlig afstraffelse fra de sognefolk, hvis kirke de havde forgrebet sig imod. Så kunne de lære det: Vil man kæmpe mod det etablerede samfund, skal man ikke tage kirkebygningen som gidsel. Det kunne aktivisterne have vidst, hvis de havde kendt deres egen historie lidt bedre.

"Kirken skal hver kristen mands hjemhus være", hedder det i Kong Eriks Sjællandske Lov fra slutningen af 1100-tallet. Oprindeligt sigtede formuleringen mod at fastslå, at der for de kristne skulle herske samme form for fredhellighed i kirkebygningen som i hjemmet. Ideen om kirken som fredhellig viste sig også, da gruppen Kirkeasyl arrangerede en protestaktion i Brorsons Kirke for 228 udvisningstruede irakere, som søgte asyl i kirkerummet sommeren 2009. På den ene side var det en håbløs aktion, som ikke havde skyggen af tidligere tiders politiske støtte. På den anden side kom det som et chok for mange at se billederne fra politiets bevæbnede fremfærd under den natlige aktion i kirkerummet (Christoffersen 2014). Men på sin vis var der tale om en ny udgave af rydningen af Hjardemål Kirke i 1970. Kirken er hellig, men i sidste instans er det staten og folkeflertallet, der bestemmer, hvad det betyder i praksis.

Kirkens ritualer og teologi har gennem århundreder gjort deres for at sikre kirkens legitimitet og kraft ved at fremhæve kirkebygningerne som Guds hus: "Herre, jeg er kommet ind i dette dit hus...", hedder det i indledningen til den i 1685 indførte 
indgangsbøn, som bruges mange steder den dag i dag (jf. Fleinert-Jensen 2013). ${ }^{4}$ I de seneste årtiers teologiske og folkeligt-eksistentielle opgør med en opfattelse af kirken og ritualerne som blot en ramme om præstens prædiken, er der sket en tydelig glidning, så kirkebygningen ikke længere blot er en metafor for den Guds kirke, som menigheden udgør. Kirkerum, ritualdeltagelse, forkyndelse og Gudsnærvær går mere eller mindre i ét, til dels i den folkelige oplevelse, men i høj grad i den kirkelige tolkning (Brinth et al 1999, 22ff.; Demant 2007; Nielsen 2007). Grundtvig satte principielt bygningerne på deres gode luthersk teologiske plads i salmebogens mest programmatiske kirkesalme

Kirken den er et gammelt hus, står, om end tårnene falde; tårne fuldmange sank $\mathrm{i}$ grus, klokker end kime og kalde, kalde på gammel og på ung, mest dog på sjælen træt og tung, syg for den evige hvile.

Vi er Guds hus og kirke nu, bygget af levende stene, som under kors med ærlig hu troen og dåben forene; var vi på jord ej mer end to, bygge dog ville han og bo hos os i hele sin vælde. Husene dog med kirkenavn, bygget til Frelserens ære, hvor han de små tog tit i favn, er os som hjemmet så kære; dejlige ting i dem er sagt, sluttet har der med os sin pagt han, som os Himmerig skænker.

(Den danske Salmebog 2003, 1.3.5).

Selv om både ordvalg og melodi kan forlede til at tro, at her prises kirkebygningens ælde, er pointen, at bygningerne med deres tårne kun er ydre rammer, der kan falde, som spiret på Vor frue Kirke gjorde det under englændernes bombardement i 1807. Kirken i teologisk forstand er ikke bygningen, men menigheden, idet bygningerne dog "er os som hjemmet så kære". Vore hjem værner vi om, selv om mange af os må opleve, at det hus, der engang var rammen om hjemmet, må sælges eller rives ned. Dette gælder måske også kirkebygningerne, når det ikke længere er rentabelt at lade dem stå? Det har været et afgørende spørgsmål i Københavns kirkeliv i mere end 30 år.

\section{Særlige forhold omkring kirkebygningerne i København}

Der er historisk bestemte statusforskelle mellem de ca. 1700 middelalderkirker og andre kirker med høj alder og bevaringsværdighed, som opleves som en del den

4 De to ældste og siden 1993 semiautoriserede alternative indgangsbønner af Anne Sofie Seidelin og Johannes Johansen taler også om kirken som Guds hus. Formuleringen er lidt mindre hyppig i nyere forslag til indgangs- og udgangsbønner fra fx Holger Lissner, Kirsten Jørgensen og Elof Westergaard. 
fælles kulturarv, og nyere kirker, som er bygget gennem en større indsats fra bestemte lokale kredse. For de nyere kirker gælder det, at bygherrens indsats fortsat kan bæres i erindring, og at kirkerne ofte ikke opleves som fælles eje på helt samme måde som de gamle kirker. I København, hvor den store kirkelukningssag udspandt sig i 2013, er der også særlige ejerforhold omkring kirkebygningerne.

Befolknings- og kirketallene for hovedstaden er langt fra en entydig historie. Først var der tale om, at befolkningsmæssig vækst blev vendt til befolknings- og ressourcemæssig deroute. Siden 1980'erne er København gået fra ressourcesvaghed til relativ ressourcestyrke med befolkningsvækst. I alle faser har kirken haltet bagefter med hensyn til at tilpasse sig forholdene. I de senere år er problemet ikke længere så meget befolkningsunderlaget, men det økonomiske grundlag i en situation, hvor medlemstallet når ned under 60 procent af befolkningen:

Befolkningstal, antal kirkebygninger og folkekirkens medlemsprocent $i$ København, Frederiksberg, Dragør og Tårnby Kommuner ${ }^{5}$

\begin{tabular}{|l|l|l|l|}
\hline Årstal & Befolkningstal & $\begin{array}{l}\text { Antal } \\
\text { kirker }\end{array}$ & Medlemsprocent \\
\hline 1860 & 163.000 & 14 & Ca. 99 \\
\hline 1960 & 890.000 & 76 & $92,8(1974)^{6}$ \\
\hline 1990 & 540.000 & 91 & $80,3^{7}$ \\
\hline 2012 & 704.108 & 90 & 60,5 \\
\hline 2027 & 854.536 (prognose) & $?$ & $?$ \\
\hline
\end{tabular}

I 1860 var der, foruden institutionskirker, i Københavns kommune kun syv sognekirker, der samtidig havde hver deres standstilknytning og historiske patronat: Vor Frue (borgerskabet), Trinitatis (universitetet), Vor Frelser og Helligånd (de handlende og håndværkerne), Holmens (flåden), Garnisons og Kastellet (hæren). Hertil kom to tyske kirker (St. Petri og den nuværende Christianskirke) samt Frederiksberg kirke fra 1734 og Brønshøj fra ca. 1180, der blev indlemmet i København Kommune i 1901. Det var uklart, hvem der skulle tage ansvar for byggeri og drift af nye kirker under befolkningseksplosionen i sidste del af 1800-tallet, hvor kongemagten og de gamle stænder var svækkede. I første omgang trådte bystyret til og fik bygget fire magistratskirker: St. Stefans på Nørrebro, St. Pauls i Nyboder, St. Jacobs på Østerbro og St. Matthæus på Vesterbro. Fra 1880 voksede den politiske modstand mod at bruge kommunale midler til kirkebyggeri, og fra 1895 til 1978 blev kirkerne primært bygget for private midler i alt 47 kirkefondskirker i Københavns kommune (Iversen 1990). ${ }^{8}$

Kilder: www.kirkenikbh.dk/nyheder /folkekirken-ikoebenhavn-ser-fremad (27.02-2013) og www.km.dk. Det første tilgængelige tal, dækkende de skattepligtige (over 15-årige) i København Kommune i 1974.

Tallet dækker Københavns stift, dvs. hovedstadskommunerne, og Bornholm.

Herunder byggedes der en halv snes rigmandskirker, institutionskirker m.fl. 
Kirkefondskirkerne var som hovedregel finansieret af private midler indsamlet af Københavns Kirkefond (især i Jylland), og blev efter anerkendelsen som sognekirker drevet af sognenes lokale menighedssamfund på Kirkefondets vegne. Efter indførelsen af menighedsråd i 1903 og senere stabile kirkelige indtægter via kirkeskat voksede både det politiske og det økonomiske pres for at få de mange kirkefondskirker ind under almindelig, folkekirkeligt styre og finansiering. Det skete gradvist, og blev for kirkebygningernes vedkommende helt gennemført ved en aftale fra 1940. Aftalen sikrede dog Kirkefondet tilbagefaldsret til kirkerne, hvis de skulle blive taget ud af folkekirkelig brug (Svendsen 1983, 39f.).

Først i 1971 var folkekirkens traditionsbundne økonomi i København fuldt ud tilpasset det nye folkekirkelige system med kirkeskat. Men den strukturtilpasning, der samme år blev foreslået af den kirkelige strukturkommission, som var nedsat af kirkeminister Bodil Koch i 1964, blev tilsidesat af den nye borgerlige regering i 1971. Men det drastisk vigende befolkningsunderlag i Københavns kommune siden 1950'erne fordrede tilpasning af den folkekirkelige økonomi. En kirkeministeriel arbejdsgruppe, nedsat 13. maj 1976, afsluttede den 20. juni 1980 sit arbejde med et forslag om otte kirkers omdannelse til filialkirker og to til annekskirker ${ }^{9}$. Forslaget måtte frafaldes pga. af massive protester fra menighedsrådene i de berørte sogne. Samtidigt steg beskatningsgrundlaget igen i København omkring 1980 pga. en del velhaveres flytning til det renoverede city, og man 'opdagede' 50 mill. kr. på en 'mellemregningskonto' i Københavns kommune (Delrapport 1, 1997, 33).

Det økonomiske pusterum blev brugt til at igangsætte en proces, der skulle hanke op i Københavns kirkeliv nedefra, da menighedsrådene tydeligvis ikke ville styres ovenfra. I 1983 blev der afholdt stormøder (sognedage) i så at sige alle kirker efterfulgt af en større kirkelig Københavnskonference, hvor man for første gang søgte at få drøftet kirkens forhold i København på tværs af de mange kirkelige grupperinger og medarbejdergrupper. Der blev yderligere fulgt op med en række historiske og kirkesociologiske studier for at få lys over situationen (Langhoff 1984; Iversen \& Thyssen 1986). Som en sidste kirkepolitisk indsats før sin afgang i 1992 førte biskop Ole Bertelsen i årene efter 1987 en kamp med kirkeministeriet for en omfordeling af stiftskapitalerne efter udskillelserne af Roskilde og Helsingør stifter og ændringer i udligningsordningen, så der kunne tages højde for de høje vedligeholdelsesudgifter til de gamle citykirker, men uden resultat.

Den nye biskop i Københavns stift fra 1992, Erik Norman Svendsen, satsede på stiftsbaserede strukturændringer og kom igennem med en provstireform, så provstigrænserne kom til at følge bydelsstrukturen. Mindre held havde han med en ny debat om 'lejlighedskirker'. I 1996 nedsatte biskoppen en tænketank, der mødte almindelig tilslutning til sin analyse i første delrapport fra 1997, men stærk modstand mod anden rapport fra 1998, der bl.a. forudsatte lukning af kirker, ligesom den foregreb stort set alle de reformer, som siden blev fremlagt i kirkeministeriets betænk- 
ning om folkekirkens lokale økonomi fra 2007 (Iversen 2010). I 2000 sagde kirkeministeriet nej til biskoppens indstilling om tildeling af status som forsøgsstift med bl.a. besluttende stiftsråd. Indtægtsgrundlaget steg igen en smule, og biskoppen oprustede med kirketællinger fra 2001 og nedsættelse af et rådgivende stiftsråd fra 2003. I 2005 blev Frederiksholm og Sjælør sogne sammenlagt, så Sjælør kirke i 2009 kunne falde tilbage til Kirkefondet, der afhændede kirken til brug for KFUM-spejderne. Et forslag fra 2007 om at tage ti kirker ud af almindelig brug blev afvist af kirkeminister Birthe Rønn Hornbech. I 2008 begyndte en proces, hvor det gamle Vesterbro Provsti blev til en fælles bykirke og senere til et fælles Vesterbro Sogn (Rasmussen 2013). Den samme udvikling fulgte en hel del langsommere også i andre bydele.

Kirkestruktursagen i København med dens beskedne resultater havde slidt hårdt på to biskopper. Den nye biskop fra 2009, Peter Skov-Jacobsen, der var valgt på et moderat program, blev snart efter sin tiltrædelse overbevist om, at kirkelukningssagen nu skulle gennemføres. I en meget omdebatteret proces nåede han med det nye, nu officielle stiftsråds støtte i 2012 frem til, at der skulle lukkes 17 kirker, der i stiftsrådets beslutning af 7. februar 2013 dog reduceredes til 14. Ud over Sjælør kirke, var tre kirker allerede de facto lukkede (Bavnehøj, Gethsemane og Fredens), mens to gamle kirkefondskirker, Samuel og Blågård, var sat til salg af Kirkefondet. Indstillingens hovedargumenter var, at der manglede penge i kassen, og der måtte skaffes penge til kirker i de nye boligområder i Nordhavn, Sydhavn og Ørestad, der i 2027 stod til at have hver et sted mellem 12.000 og 17.000 indbyggere uden kirke i bebyggelserne (Krudthøffer 2013).

\section{Kulturministerens afgørelse i 14 kirkelukningssager i København 2013}

Kirkeminister Manu Sareen erklærede sig inhabil til at afgøre Københavns biskops indstilling af 14 kirker til lukning, da han flere gange havde markeret sig som en stærk tilhænger af kirkelukningerne. Sagen blev derfor overladt til kulturminister Marianne Jelved. Hendes afgørelse ved breve til de 14 menighedsråd samt biskoppen den 14. september 2013 indebar, at seks kirker lukkedes, mens to blev taget ud af sognekirkelig brug, hvor menighedsråd og biskop var enige om det, mens seks andre kirker, der af biskoppen og stiftsrådet var indstillet til lukning mod menighedsrådets vilje, ikke lukkedes. ${ }^{10}$

Afgørelserne tydeliggjorde en række grundprincipper i forholdet mellem folk, stat og kirke, for så vidt angår forvaltningen af kirkebygninger:

10 Pressemeddelelse og skrivelser i sagen kan findes på http://kum.dk/nyheder-og-presse/presse meddelelser/2013/september/afgorelse-i-14-kirkelukningssager-i-kobenhavns-stift/ (besøgt 1.1.2014). 
1. Staten/ministeren afgør suverænt ved et forvaltningsmæssigt skøn sager om kirkelukninger og fastsætter regler for fremgangsmåder ved afhændelse af kirkebygninger, principielt ubundet af kirkelige instansers indstillinger (jf. afsnit om "Gældende ret" i brevene til menighedsrådene). Ved afgørelserne har ministeren inddraget personlige møder med alle sagernes parter samt en vurdering af alle former for anvendte argumenter i indstillingerne, særligt dog 1) proportionalitet mellem problemet og løsningsforslaget og 2) konsistensen i argumentationen og især sammenligningsgrundlaget, når bestemte kirker indstilles til lukning frem for andre.

2. Staten/ministeren følger så vidt muligt det lokale menighedsråds flertals indstilling, selv om statens afgørelse principielt hviler på retlige og forvaltningsmæssige argumenter. Siden 1903 er ingen kirke nedlagt mod menighedsrådets vilje, hvilket angiveligt flugter med, at det "er menighedsrådet, der lovgivningsmæssigt har fået til opgave at skabe det gode kirkelige liv i sognet" (jf. afgørelserne om de seks ikke-lukkede kirker).

3. Provenuet ved salg af kirkebygninger tilkommer den lokale kirkekasse formelt på sogne- men reelt på stiftsplan - på linje med, hvad der gælder ved salg af andre kirkelige ejendomme. Proceduren for og tilsynet med afhændelse af kirkebygninger fastlægges af stiftsøvrigheden.

4. Kirker, der tages ud af normal folkekirkelig brug, mister dermed status i forhold til kapitel 1 i Lov om kirkers brug. Er der tale om bevaringsværdige kirker, kan de i stedet fredes efter fredningslovens bestemmelser. Når en kirke overgår til kombineret kirkelig og anden brug, fx under en fondskonstruktion via tilbagefald til kirkefondet, må menighedsrådet ikke give tilskud til en sådan fonds drift, men gerne leje lokaler hos fonden.

5. Kirker kan tages ud af normal sognekirkelig brug og drives videre så vidt muligt udgiftsneutralt via brugerbetaling og indtægtsdækket virksomhed. Udgifter til vedligeholdelse påhviler folkekirken, så længe kirkebygningen fortsat er underlagt provstesyn og stiftsøvrighed.

Det samlede forløb tydeliggør samtidig de p.t. herskende praktisk-politiske vilkår omkring ændringer i kirkebygningernes status:

1. Den sikreste og praktisk talt eneste vej til nedlæggelse af kirkebygninger er sammenlægning af sogne, hvor et menighedsrådsflertal finder ud af at rationalisere storsognets drift med færre filialer.

2. Holdningen til kirkelukninger blandt biskopper og stiftsråd følger graden af disses direkte medansvar for kirkens økonomi, som er høj i Københavns kommune/stift, hvor alle penge fordeles fra et fælles budgetudvalg på kommuneplan, og lav i stifter med mange små kommuner/provstier og evt. gode tilskud via udligningsordningen. 
3. Kirkeministeren kan - som repræsentant for den enevældige stats kirkeforvaltning - ikke ytre sig kirkepolitisk uden at risikere at blive inhabil som suveræn forvaltningsmyndighed. Kirkeministeren må ikke optræde som politisk leder, selv om det er, hvad en minister normalt må være.

4. Stadfæstelsen af menighedsrådet som næsten suveræn kirkebestyrelse, under tilsyn af stiftsøvrigheden, betyder en øget kirkeliggørelse af kirkebygningerne, selvom folkekirkens menighedsråd ikke ejer, men kun bestyrer kirkebygningerne. Den politiske logik i den nuværende folkekirkeordning er, at jo mere suverænitet staten har over kirken, jo mere er staten tvunget politisk til at overlade styret af kirkebygningerne til de lokale menighedsråd.

5. Folkeligt valgte kirkebestyrelser og statsligt tilskud til museal vedligeholdelse af de gamle middelalderkirker kunne sikre en proportional adgang for alle grupper i sognet til at bruge kirkerne. Samtidig kunne bindingen mellem den folkekirkelige menighed og kirkebygningen løses op. Men sagen er endnu ikke politisk moden: I den sommeren 2014 pågående politiske debat om folkekirkens styrelse, ser det ud til, at forslagene omkring en begyndende oprydning i sammenblandingen mellem statslig og kirkelig finansiering i folkekirken, som har været diskuteret i folkekirken i 25 år, nok engang skydes til hjørne (534 høringssvar).

Sammenfattende kan det konstateres, at kulturministerens afgørelse i forbindelse med kirkelukninger er så politisk klogt gennemført, at det let kan forhale lovgivning på området. Dette selv om både kirkeministeren og biskopperne efter afgørelserne sagde meget højt at det var, hvad de ønskede sig muligvis som en manøvre, der kan udsætte den næste ubehagelige runde med kirkelukningsdebat.

\section{Konklusion: Kirkebygningerne som hellige køer}

De folkekirkelige kirkebygninger befinder sig i grænselandet mellem kirken og den fælles kulturarv. Vanskelighederne med at håndtere deres brug, især i diskussioner om kirkelukninger, skyldes ikke mindst, at de forskellige aktører ikke har gjort sig denne stilling klar - og især, at der ikke er skabt en forvaltningsstruktur omkring kirkerne, som afbalancerer de kirkelige og folkelige interesser.

I den foreliggende situation må kirkebygninger i Danmark håndteres med samme delikatesse og strategiske indføling som de hellige køer i Indien. Kirkebygningerne er ikke hellige køer i udtrykkets overfladiske betydning om fænomener og personer, som enten ikke må kritiseres eller som på den ene eller den anden måde er resistente 
overfor kritik. Men de danske kirkebygninger ligner de hellige køer i Indien på nogle mere subtile og dybtliggende måder. ${ }^{11}$

Selv om der i begge tilfælde er en slags ejer eller forvalter, som har brugsretten, kan ejeren ikke disponere over køerne eller kirkerne, som man normalt gør det over sin ejendom. Man kan ikke blot skaffe køerne eller kirkerne af vejen. I den forstand er de hellige eller urørlige, fordi det vil være helligbrøde - og ofte også direkte ulovligt - at gøre kort proces, som vi i Vesten ellers gør det med dyr eller bygninger, som det ikke længere er rentabelt eller på anden måde attraktivt at holde liv i. Hellige køer og kirkebygninger kan ikke handles eller genbruges efter forgodtbefindende.

Det er uklart både i hinduistisk tradition og i det sekulære Danmark, hvad det vil sige at være 'hellig'. Køer i Indien og kirkebygninger i Danmark har en nærmest ontologisk status, der hæver dem over fx den ellers allestedsnærværende konkurrencekapitalisme. Det ellers fremherskende folkekirkelige slogan 'Mere kirke for pengene' suspenderes, når det gælder kirkebygninger. Beslutter ejeren, at det nu er på tide at få skaffet nogle køer i Indien eller kirker i Danmark af vejen, så man kan få en mere rentabel drift på ens område, må det ske ad omveje, typisk gennem mellemhandlere. Indiske køer kan sendes 'til landsbyen', hvor de ofte hurtigt bliver slagtet, selv om udtrykket antyder, at de skal leve videre på de evige græsmarker. Danske kirker skal igennem lange og besværlige procedurer, før de måske kan overgå til en anden for dem værdig brug.

Hertil kommer endelig, at såvel de indiske køer som de danske kirkebygninger indgår i den nationale religionskamp, som især højrefløjskræfter i såvel Indien som Danmark fører mod de indvandrede muslimer. Nationalistiske hinduer mener, at muslimerne begår helligbrøde, når de spiser oksekød, og nationalistiske danskere kæmper for, at kirkebygningerne skal bevares og fortsat have monopol på at stå med deres høje tårne i det danske landskab.

\section{LITTERATUR}

Andersen, Steen Skovsgaard

1992 "Fra statskirke til folkekirke. Kirkeforfatningsspørgsmålet 1848-1901", Kirkehistoriske Samlinger, 147208.

Betænkning 1491

2007 Folkekirkens lokale økonomi, Kirkeministeriet.

Betænkning 1511

2009 Omlægning af Statens tilskud til folkekirken, Kirkeministeriet.

Brinth, Ole, Helle Christiansen, Henrik Christiansen \& Marianne Christiansen

1999 Højmessen i Den Danske Folkekirke. En liturgisk håndbog, Anis, Frederiksberg.

1997 og 1998 Delrapport fra tænketanken 1 og 2, Københavns Stift.

Christoffersen, Lisbet

2014 "Sacred Spaces in Secular (Post)-Lutheran Contexts", in: Rosemarie van den Breemer, Jose Casanova

11 De her anvendte oplysninger om de hellige køer i Indien stammer Doniger 2011, 657-659 og 727. Tak til lektor Peter B. Andersen for indføring i emnet. 
\& Trygve Wyller, eds., Secular and sacred? The Scandinavian Case of Religion in Human Rights, Law and Public Space, Vandenhoeck \& Ruprecht, Göttingen, 102-122.

Fleinert-Jesen, Flemming

2013 "Herren bevare din indgang og din udgang", Præsteforeningens Blad, 608-612. 638-642.

Demant, Jørgen

2007 "Gudstjenestens rum", in: Helle Christiansen \& Henning Thomsen, eds., Pastoralteologi, Anis, Frederiksberg, 97-113.

Doniger, Wendy

2011 The Hindus. An Alternative History. Penguin Books, New Delhi [2009].

Højsgaard, Morten Thomsen \& Hans Raun Iversen

2013 Danskernes tro anno 2013 - spørgsmål og svar, http://www.teol.ku.dk/cfk/yougov-undersoegelse/ (besøgt 20.6.2014).

Iversen, Hans Raun

2012 "Den danske folkekirke i nordisk belysning", in: Lisbet Christoffersen et al., eds., Fremtidens danske religionsmodel, Anis, Frederiksberg, 23-40.

2010 "Folkekirken som den fremtræder og definerer sig selv - Betænkning 1377 og 1491 og efterfølgende lovgivning", in: Bekendelse og kirkeordninger. Kirkeretsantologi 2010, Selskab for kirkeret. København og Århus, 127-150.

2003 "Kirkeministeren kan ikke fastsætte regler...", Dansk Kirkeliv, 53-58.

1993 "Folkekirkeordningens udvikling", in: Margrethe Auken et al., eds., Kirkens mund og mæle, Anis, Frederiksberg, 173-185.

1990 "Baggrund for og hovedtemaer i kirkesynsdebatten omkring Kirkefondet", in: Claus Harms et al., eds., Omkring Kirkefondet, Religionspædagogisk Center, Frederiksberg, 15-38.

Iversen, Hans Raun og Anders Pontoppidan Thyssen, eds.,

1986 Kirke og folk i Danmark. Kirkesociologisk Dokumentation, Anis, Århus.

Kruhøffer, Annette

2013 "Et forudsigeligt nederlag", Arken 156, Det Teologiske Fakultet, København, 6-12.

Langhoff, Johannes red.

1984 Glæden for hele folket. Foredrag og debatter på konferencen om folkekirken i København 18.-20. november 1983, Københavns Stift.

Malmgart, Liselotte

2003 Vilkår for liv og vækst. Menighedsrådsloven 1903-2003, Landsforeningens Forlag, Århus.

Munk, Kaj

1948 Mindeudgave. Prædikener, Nyt Nordisk Forlag Arnold Busck, København.

Nielsen, Bent Flemming

2007 "Kirken som rituelt rum", in: Helle Christiansen \& Henning Thomsen, eds., Pastoralteologi, Anis, Frederiksberg, 83-96.

Svendsen, Erik Norman

1983 "Sognetyper og menighedsformer i Købehavn historisk belyst", Kritisk Forum for Praktisk Teologi 14, 27-51.

Rapport fra arbejdsgruppen om folkekirkens kirker, der helt eller delvis tages ud af brug.

2013 Ministeriet for Ligestilling og Kirke.

Rasmussen, Andreas

2013 "Folkekirken på Vesterbro", in: Bjerring-Nielsen et al., eds., Den mangfoldige kirke: Menighedsformer $i$ Danmark, Dansk Missionsråd, Frederiksberg, 87-96.

Stenbæk, Jørgen

2003 "Folkekirkens ejendomsforhold og økonomi - historisk belyst", Kirkehistoriske Samlinger, 123-148.

Wiwel, Mikael

2013 Kunsten i kirken. Strandberg Publishing, København. 
534 høringssvar på betænkningen om Folkekirkens styre.

http://www.km.dk/no_cache/ministeriet/nyheder/single-news/artikel/534-hoeringssvar-paa-

betaenkningen-om-folkekirkens-styre-1/ (besøgt 7.6.2014)

Hans Raun Iversen, lektor, cand. theol. Afdeling for Systematisk Teologi, Københavns Universitet 